\title{
Challenges of THE Challengers: An InSight INTO THE INTERNATIONALIZATION PATHWAY OF Croatian Digital Agencies
}

\author{
Nikola Draskovic, Milivoj Markovic \& Domagoj Hruskar
}
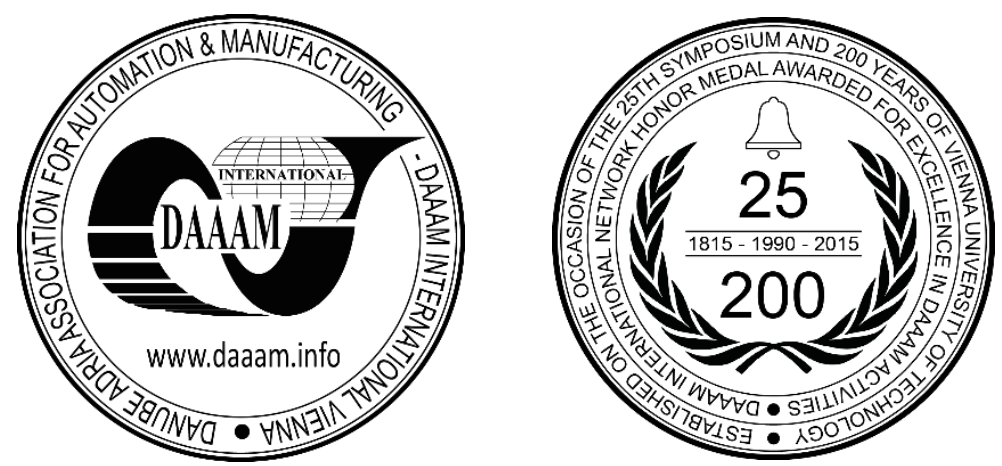

This Publication has to be referred as: Draskovic, N[ikola]; Markovic, M[ilivoj] \& Hruskar, D[omagoj] (2017). Challenges of the Challengers: An Insight into the Internationalization Pathway of Croatian Digital Agencies, Proceedings of the 28th DAAAM International Symposium, pp.0895-0901, B. Katalinic (Ed.), Published by DAAAM International, ISBN 978-3-902734-11-2, ISSN 1726-9679, Vienna, Austria

DOI: $10.2507 / 28$ th.daaam.proceedings. 124

\begin{abstract}
Development of internet-based technologies provided companies with an ideal infrastructure for rapid internationalization. The internet era facilitated the emergence of a new type of companies that rapidly develop global presence through the utilisation of various internet-based technologies. According to the traditional internationalization theories, the process of internationalization requires vast amounts of funds, significant time, competent international workforce and network support by suppliers. The so cold born global companies rely far less on these elements (prerequisites). For them, the development of internet infrastructure and the overall market penetration of internet are much more essential. Their process of internationalization (or globalization) is usually rapid, without any preceding longterm domestic or internationalization phase. This paper analyses theoretical framework behind the born global companies' internationalization process in order to shed some light on the recent developments among Croatian digital agencies and their internationalization pathways. Although born global companies are challenging traditional theories, there exists a scope for potential complementarity between these essentially opposite pathways of internationalization.
\end{abstract}

Keywords: internet-based technologies; digital agencies; internationalization; born global companies.

\section{Introduction}

With around 4.2 million inhabitants and GDP per capita at EUR 10,162 [1], Croatia is fairly small and emerging market. Typically, local companies focused on growth are forced to internationalise their business activities in relatively short time span. In other words, Croatian companies cannot maintain sustainable growth focused solely on the local market. During the latest economic downturn, Croatian companies focused on exporting activities performed above the average [2]. Traditionally, a Croatian company will initiate its internationalization process by entering one or more markets within the region (i.e. the area of former Yugoslavia), which is fairly close geographically and with modest cultural distance. Encouraged by regional success, a company will probably consider entering markets outside the region. The whole process will take time and it requires vast amounts of capital, often times attainable only at a high cost. 
Therefore, companies are highly incentivised to seek alternative approaches. With the development of internet and internet-based technologies, a completely new sales and promotion channel emerged, giving small and medium enterprises (SMEs) and opportunity to rapidly scale their business internationally.

The aim of this paper is to analyse and contrast traditional internationalization theories and the born global phenomenon, or the process of rapid globalization, in the context of the Croatian digital agencies' internationalization process. Furthermore, this paper also serves a purpose of a preliminary study with the intention to plot a path for further research of this topic. From the methodological standpoint, this paper is based on the literature review and research of secondary sources addressing the phenomenon of recent Croatian digital agencies internationalization efforts.

\section{An overview of internationalization theories: the organic versus born global}

Figure 1 represents a concise comparison between two opposite pathways of internationalization. In the context of a company's internationalization, the organic pathway (or the Uppsala model) represents more traditional and timeconsuming approach. On the opposite side, born global pathway represents an accelerated process of internationalization that takes less time, but is also riskier from the company's perspective.

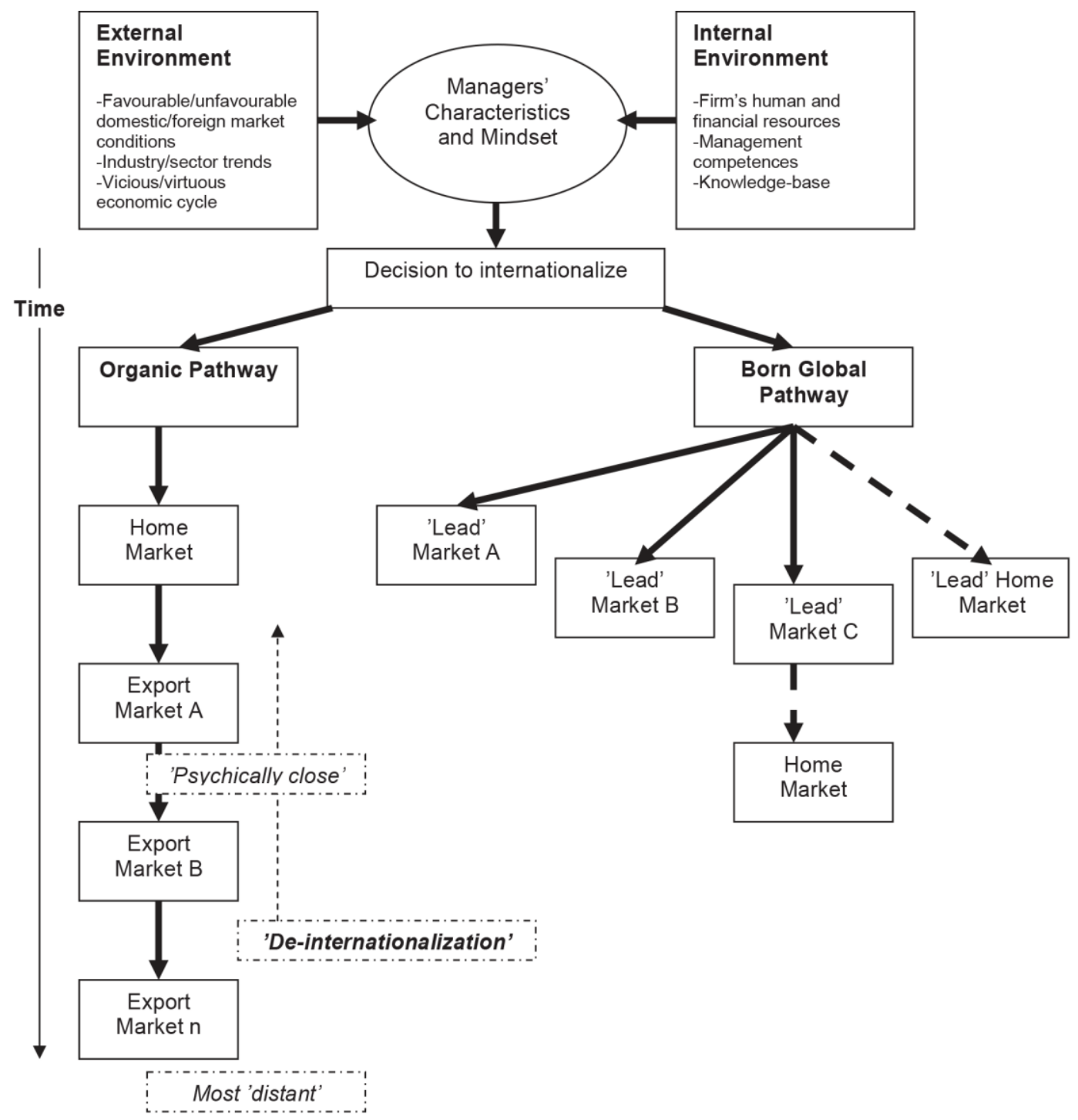

Fig. 1. Two extreme pathways of software firm internationalization: the organic pathway (Uppsala model) versus born global [3]

\subsection{The Uppsala internationalization model}

Researchers at the University of Uppsala in Sweden developed the Uppsala internationalization model in late 1970s in order to develop a better understanding of internationalization pathways. The theoretical framework was built around observations and analysis of Swedish manufacturing companies and their internationalization processes [4]. 
According to the research findings, Swedish manufacturing companies usually started their international operations in countries that were relatively close geographically and further internationalization will continue in small incremental steps. Commonly, companies will enter new markets through exports. However, after several years a company will increase its foreign market commitment.

As Figure 2 implies, the Uppsala model has two main interacting and mutually influencing parts - state factors and change factors. As the company cumulates experience, its market knowledge increases, which influences the commitment decisions. With the increasing commitment, company increases the level of activities, which leads towards cumulating new experience and gaining new knowledge.

The concept of market commitment recognizes just two factors - the amount of resources (i.e. investment) committed and the degree of commitment (i.e. the complexity of discovering an alternative use for the resources and relocating them to the alternative use) [5]. Besides the aforementioned geographical proximity, another important factor influencing the degree of commitment and new market entry is the psychic distance. [6]

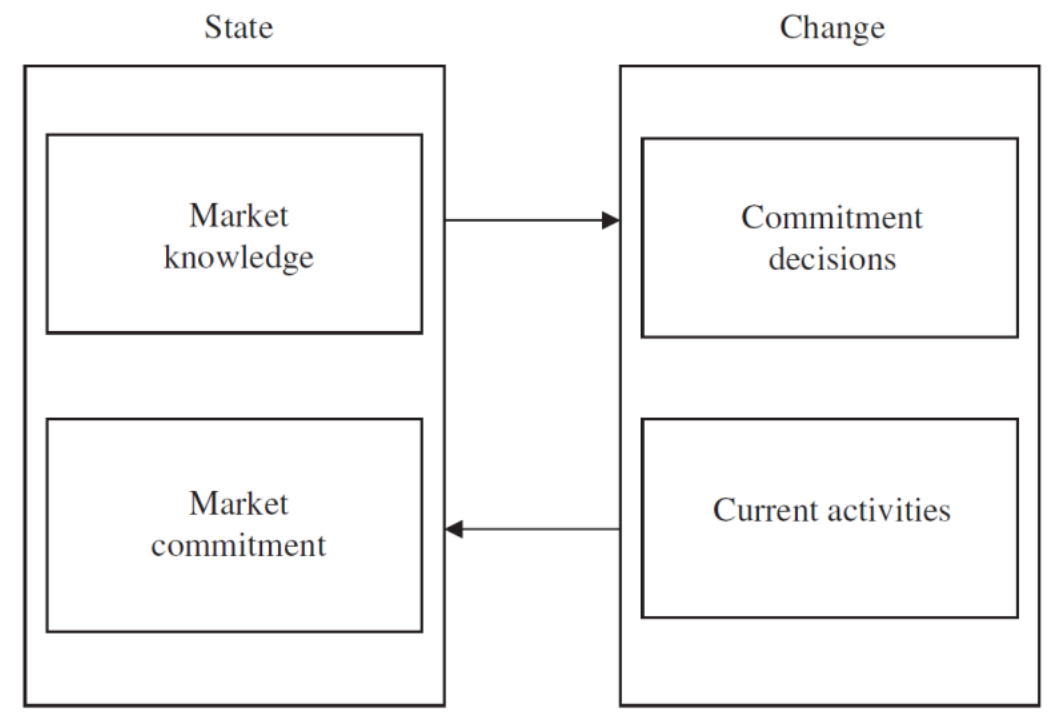

Fig. 2. The original Uppsala model [7]

Johanson and Wiedersheim-Paul [4] identified four foreign market entry modes or stages with different levels of international involvement:

- Stage 1: no regular export activities or just sporadic export

- Stage 2: export via independent representatives

- Stage 3: establishment of a foreign sales subsidiary

- $\quad$ Stage 4: foreign manufacturing units

According to the Uppsala model, a company will move through successive stages increasing its international market commitment. Obviously, it is a slow and iterative process, but with a reason. As more recent research suggests [8], market's high complexity and overall uncertainty call for a slow, thorough approach to internationalization. Business risk is often too high for bold and quick decisions about new market entries.

Due to the increasing complexity and challenges of the global market, a need for further improvement of the original Uppsala model emerged. Consequently, the importance of company's business networks has been recognized as a success factor [9], which lead to the revision of the original Uppsala model [10].

According to the study of the internationalization process of SMEs [11], companies tend to rely on their relations with upstream and downstream networks while selecting the market and the mode of entry. In other words, the relationships that a company develops and maintains in a domestic network can be used as bridges to similar networks abroad [6]. The revised model (Figure 3) emphasises the fact that the internationalization process takes place within the network context [12]. The company's network position is influenced by the activities such as learning, creating and trust-building. 


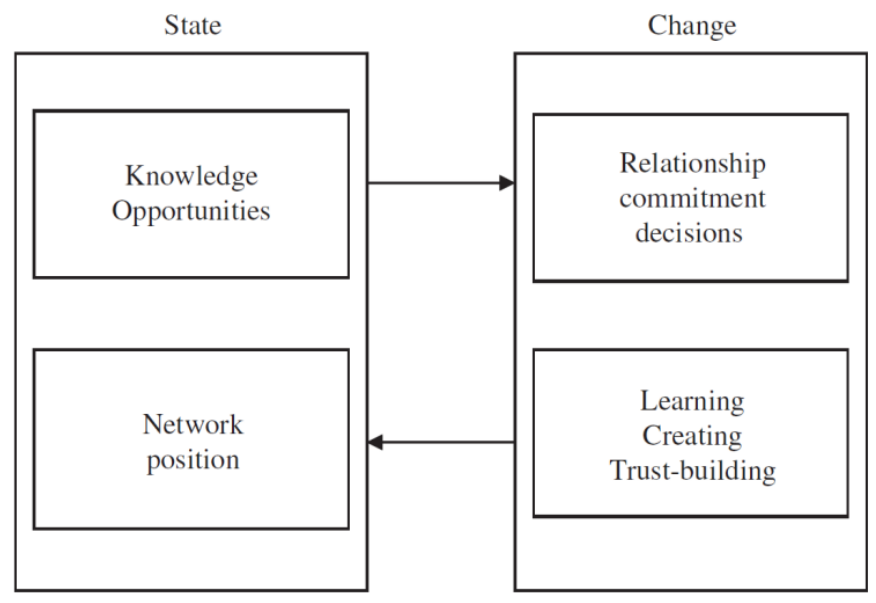

Fig. 3. The revised Uppsala model with the application of a basic networking prospect [10]

Subsequent research has examined complementary variables to the ones originally considered by Uppsala model which added to the understanding of the internationalization pathways of companies. Research has examined cultural distance and found support for the proposition that when internationalizing, companies tend to choose markets and countries that exhibit closer cultural distance to their current markets [13] [14]. Institutional distance was also found to be a significant factor when businesses chose a host country for internationalization. In general, evidence support the fact that companies tend to choose host countries for foreign entry which exhibit smaller institutional distance vs. countries which exhibit larger institutional distance [15] [16].

Common to these studies is that, similarly to Uppsala model, they look on internationalization pathways of companies as gradual processes that companies engage into by analysing similarities (different measurements of "distance") between the markets/countries they are present in and the new ones they are targeting for entrance. As is analysed next, there exist a number of companies that do not fit any of the internationalization pathways presented so far.

\subsection{Born global}

Globalization processes, fuelled by advances in technology and communication, and removal of trade barriers, have resulted with dramatic changes and challenges within the companies' environment. However, with these disruptive changes, new business opportunities emerged. Noticed by researchers in the recent years, there is an increasing number of companies riding the wave of globalization that do not follow traditional internationalization stages pattern [6]. Instead, their globalization process is accelerated, without any preceding time-consuming step-by-step internationalization.

Born global can be defined as companies that, from the start-up, follow a vision of becoming global and usually rapidly globalize their business activity, skipping long-term domestic or internationalization phase [17] [18]. Born globals are typically SMEs with rapid globalization strategy from the moment of their inception or soon after. More strict definition suggests that the born global company has to rapidly internationalise its business within three years from the inception and its international activities should account for at least 25\% of the total revenue [19]. Many researchers contributed to the identification of the reasons behind the emergence of the born globals. Some of the most common are the following [20] [21] [22]:

- Small domestic niche markets,

- Uniqueness of the product/service

- Globalization of sourcing activities and financial markets,

- Technological development (especially in the field of internet-based technologies, communication and logistics),

- Founders and employees are nowadays more capable of doing international business thanks to the possibilities of modern technology,

- Quick acquisition of international experience and knowledge,

- Existence of international networks that support global business activities.

In the traditional model, the risk related to the uncertainty of the foreign market entry is typically hindering companies' internationalization efforts. However, the increased level of globalization in some industries contributes to the lowering of the perceived risk of entering foreign markets, creating a kind of me-too effect among SMEs [23]. Thus, the born global approach requires certain level of entrepreneurship and risk-taking among founder(s) [24]. Due to a different level of internationalization, there are different types of born global companies [19] [25]:

- Born regionals - international companies focused on markets within their region,

- Born internationals - companies with focus on low-distance markets,

- True born globals - companies focusing on both low- and high-distance markets

- Born-again globals - companies previously focused only on domestic markets, which at some point embrace rapid and dedicated internationalization 
It is often argued that internet capabilities have strongly impacted emergence of born global companies by offering a plethora of opportunities for SME's to quickly expand their global reach and market presence [26]. Most common case analysed, for which research has provided positive evidence, is the pervasive use of internet [27] as a marketing channel in accessing global markets. While positive effects have been found, researchers note that internet cannot be considered as a substitute to physical market presence, it does however contribute positively to company performance [28] [29].

\section{Croatian digital marketing internationalization efforts}

\subsection{An overview of the Croatian digital marketing industry}

For decades, Croatian marketing industry was tightly linked with the political and economic developments. After the period of socialism, Croatia started its transition towards democracy and free market in early 1990s. That was the era when a majority of established local marketing agencies either bankrupted or were acquired by some large international advertising network [30]. Additionally, a large number of micro and small agencies emerged, usually founded by former employees of the bankrupted agencies. Some of them managed to survive harsh economic environment of the post-war Croatia, while majority simply disappeared over the years. Soon, the marketing industry was dominated by international networks (e.g. McCann-Ericksson, BBDO, Grey), together with a number of smaller local agencies. In the mid 2000s, marketing industry bloomed reaching yearly revenues at EUR 500 million [31]. The global economic downturn in 2007/2008 had heavy impact on the Croatian economy. The marketing communications budgets of companies in Croatia deflate, resulting with the sinking of the whole marketing industry and new bankruptcies among local agencies.

Unfortunately, Croatian marketing industry did not manage to recover in the past decade. According to the available reports [32], Croatian marketing communications industry is currently worth around EUR 200 million. Similar to the global trends [33], digital side of marketing is continuously growing, while traditional marketing communications and traditional media are stagnating. More or less, all marketing communications agencies in Croatia offer digital marketing service, with no exception among the biggest traditional agencies [34]. On average, digital marketing contributes around $26 \%$ to the traditional agencies' revenues [35].

The growing number of newly founded digital agencies initiated the transition of traditional agencies towards digital marketing. While traditional agencies simply added a digital department to their organization structure, digital agencies were usually micro or small start-ups exclusively focused on the digital aspect of marketing. Since the founding of a digital agency does not require some large-scale investment, entry barriers for new players are quite low, resulting with an inflation of digital agencies in Croatia right now [36]. While the overall marketing industry and media expenditure is stagnating, the increasing number of digital agencies escalated competition, resulting with the decline of service fees.

\subsection{Internationalization specifics of Croatian digital marketing agencies}

Faced with international competition within their domestic market, internationalization through an organic pathway is a common growth strategy for the traditional Croatian marketing agencies. Consequently, many of them entered neighbouring markets, such as Bosnia or Serbia, mostly due to small geographic and cultural distance. The common entry modes are usually joint ventures with local agencies or acquisitions. Direct investments are not that common. Although, there are also some exceptions. For example, Bruketa \& Zinic agency expanded its business to Belgrade and Vienna (which counts as a region), and, in 2011, the agency established a subsidiary in Baku (Azerbaijan) after winning a local telecom account [37]. However, the agency withdraw from both Baku and Belgrade this year, after selling its share to the WPP group and merging with Grey Croatia [38]. Obviously, the agency did not have sufficient funds to continue with its internationalization process and the owners switched to de-internationalization strategy.

While for the traditional agencies, establishing a foreign subsidiary is a time consuming process that requires vast amounts of money and significant risk-taking, the internationalization pathway of Croatian digital agencies seems to be less complex. Typically, a digital agency will, at the beginning, look for some additional business opportunities within the region using internet and social media for communication with prospects. This way, an agency does not have to establishing a subsidiary abroad, which reduces risk and investment. If the business would not develop as expected, an agency will simply change its focus to another market.

Besides regional strategies, digital agencies are also developing selective international and global strategies. Usually, they target just a few developed markets, such as UK, US or Germany. Although a majority of prospecting activities and communication is conducted online, agencies sometimes rely on the assistance of local agents. Local representation is especially needed in distant markets, such as US, due to both geographic and psychic distance.

It is a job of local representative to bridge this distance and to close a deal with the prospect found either by him/her or by a domestic sales representative.

The main question that arises at this point is how a digital agency from Croatia can compete on these highly competitive markets? The business model of Croatian digital agencies is very simple. The only really internationalized part of the company is the sales department, while all the job is done locally, in Croatia. This way, a Croatian digital agency utilises home country cheaper labour and offers same services as the host country agencies, but at lower price. Potentially, this looks like a very sustainable born global strategy that benefits from both the development of internet based technologies and increasing budgets for online advertising. The only potentially negative development that may threat this business model is the emergence of similar agencies from countries with even cheaper highly skilled labour. 


\section{Conclusion}

This paper contrasts two leading and competing approaches to internationalization by revisiting their key tenants and contrasting them with development paths of Croatian digital marketing agencies. It is evident that support exist for the proposition that Croatian digital marketing agencies have bypassed traditional internationalization pathway (stage-bystage approach) as described by Uppsala model (and subsequent extensions) and opted for a fast and far-flung internationalization approach (born global).

Using internet marketing channels, well-educated and cost competitive workforce, and building on their domestic experience, they have been able to successfully enter regional markets as well as more distant ones. However, it would seem that greater challenge from entering foreign markets (winning initial accounts) is establishing firm market position and scaling the business on those markets in order to sustain pressures from competition. It would also seem that Croatian digital marketing agencies have successfully used the possibilities provided by internet to establish international presence (born global approach) with a combination of traditional stage models of internationalization (short "distanced" regional expansion).

Future research endeavours should explore internationalization pathways among the regional digital marketing agencies which could support the finding here on multicountry basis. From the methodological standpoint, instead of secondary data analysis, researchers should opt for primary data collecting, ideally through series of in-depth interviews with managers from digital marketing agencies. Also, it would be worth exploring the validity of born global approach in other industries impacted heavily be digital technology. Although internet provides opportunities for fast and distant internationalization the key challenge apparently revolves around how to scale the business once the market has been entered.

\section{References}

[1] Ostroski, L. (Ed.) (2015). Hrvatska u brojkama/Croatia in Figures - 2015, State Bureau of Statistics of Republic of Croatia, Zagreb, ISSN 1848-6673 Ostroski, L. (Ed.) (2015). Hrvatska u brojkama/Croatia in Figures - 2015, Državni zavod za statistiku Republike Hrvatske, Zagreb, ISSN 1848-6673

[2] Sector of International Affairs/EEN (2015). Internationalization and Financing: Committee of Republic of Croatia for Internationalization of Croatian Economy, Croatian Chamber of Commerce, Zagreb. Sektor za medjunarodne poslove/EEN (2015). Internacionalizacija i mogućnosti financiranja: Povjerenstvo Vlade Republike Hrvatske za internacionalizaciju hrvatskog gospodarstva, Hrvatska gospodarska komora, Zagreb

[3] Âijö, T., Kuivalainen, O., Saarenketo, S., Lindqvist, J. \& Hanninen, H. (2005). Internationalization Handbook for the Software Business, Centre of Expertise for Software Product Business, ISBN: 952-99529-1-0, Espoo

[4] Johanson, J. \& Wiedersheim-Paul, F. (1975). The internationalization of the firm - four Swedish cases. Journal of Management Studies, Vol. 12, No. 3, 1975, pp. 305-323, ISSN: 1467-6486

[5] Andersen, O. (1993). On the internationalization process of firms: a critical analysis. Journal of International Business Studies, Vol. 24, No. 2, 1993, pp. 209-231, ISSN: 0047-2506

[6] Hollensen, S. (2017). Global Marketing, Pearson Education, ISBN: 978-1-292-10011-1, Harlow

[7] Johanson, J. \& Vahlne, J.E. (1977). The internationalization process of the firm: A model of knowledge development and increasing foreign market commitments. Journal of International Business Studies, Vol. 8, No. 1, 1977, pp. 2332, ISSN: 0047-2506

[8] Vahlne, J.E., Ivarsson, I. \& Johanson, J. (2011). The tortuous road to globalization for Volvo's heavy truck business: extending the scope of the Uppsala model. International Business Review, Vol. 20, No. 1, 2011, pp. 1-14, ISSN: 0969-5931

[9] Johanson, J. \& Vahlne, J.E. (1990). The mechanisms of internationalization. International Marketing Review, Vol. 7, No. 4, pp. 11-24, 1990, ISSN: 0265-1335

[10] Johanson, J. \& Vahlne, J.E. (2009). The Uppsala internationalization process model revisited: From liability of foreignness to liability of outsidership. Journal of International Business Studies, Vol. 40, No. 9, 2009, pp. 14111431, ISSN: 0047-2506

[11] Coviello, N.E. \& Munro, H.J. (1997). Network relationships and the internationalization process of smaller software firms. International Business Review, Vol. 6, No. 4, 1997, pp. 361-384, ISSN: 0969-5931

[12] Hosseini, M. \& Dadfar, H. (2012). Network-based theories and internationalization of firms: applications to empirical studies. The Business \& Management Review, Vol. 3, No. 1, November 2012, pp. 182-191, ISSN: 20470398

[13] Goerzen, A., \& Beamish, P.W. (2003). Geographic scope and multinational enterprise performance. Strategic Management Journal, 24, 1289-1306.

[14] Filippaios, F., \& Rama, R. (2011). Cultural distance and internationalization: The world's largest food and drink multinationals. Agribusiness, 27(4), 399-419. doi:10.1002/agr.20283

[15] Gama, M. A. B., Lana, J., Vilasboas Calixto, C., \& Bandeira-de-Mello, R. (2016). Business group internationalization: Choosing a host country according to institutional distance. Review of Business Management, 18(61), 327-347. doi:10.7819/rbgn.v18i61.2894

[16] Pogrebnyakov, N., \& Maitland, C. F. (2011). Institutional distance and the internationalization process: The case of mobile operators. Journal of International Management, 17(1), 68-82. doi:10.1016/j.intman.2010.12.003 
[17] Luostarinen, R. \& Gabrielsson, M. (2004). Finnish perspectives of international entrepreneurship, In: Handbook of research on international entrepreneurship, Dana, L.P. (Ed.), pp. 383-403, Edward Elgar Publishing, ISBN: 184376069X, Cheltenham

[18] Oviatt, B. M., \& McDougall, P. P. (1994). Toward a theory of international new ventures. Journal of International Business Studies, Vol. 25, No. 1, 1994, pp. 45-64, ISSN: 0047-2506

[19] Kuivalainen, O., Sundqvist, S. and Servais, P. (2007). Firms' degree of born-globalness, international entrepreneurial orientation and export performance. Journal of World Business, Vol. 42, No. 3, 2007, pp. 253-267, ISSN: 1090-9516

[20] Knight, G.A. \& Cavusgil, S.T. (2004). Innovation, organization capabilities, and the born-global firm. Journal of International Business Studies, Vol. 35, No. 2, 2004, pp. 124-141, ISSN: 00472506

[21] Andersson, S. \& Wictor, I. (2003). Innovative internationalisation in new firms: born globals - the Swedish case. Journal of International Entrepreneurship, Vol. 1, No. 3, 2003, pp. 249-275, ISSN: 1570-7385

[22] Madsen, T. K. \& Servais, P. (1997). The internationalization of born globals: an evolutionary process?, International Business Review, Vol. 6, No. 6, 1997, pp. 561-583, ISSN: 0969-5931

[23] Verdier, S., Prange, C., Atamer, T. \& Monin, P. (2010). Internationalization performance revisited: the impact of age and speed on sales growth. Management International, Vol. 15, No. 1, 2010, pp. 19-31, ISSN: 1206-1697

[24] Andersson, S. \& Florén, H. (2009). Exploring differences in the work of owner-managers in small international and non-international firms. Competitive paper presented at the 12th McGill International Entrepreneurship Conference Hanken School of Economics, Vaasa, Finland September 18-20.

[25] Bell, J., McNaughton, R. \& Young, S. (2001). "Born-Again Global" Firms: An Extension to the "Born Global" Phenomenon. Journal of International Management, Vol. 7, No. 3, 2001, pp. 1-17, ISSN: 1075-4253

[26] Marcus Vinicius de Oliveira Brasil, Ogasavara, M. H., Francisco Correia de Oliveira, Tassigny, M. M., \& Raimundo Eduardo Silveira Fontenele. (2013). the role of internet in the born global companies. Revista De Administração Da UFSM, 6(2), 431-442. doi:10.5902/198346599061

[27] Simicevic, V.; Zoroja, J. \& Pejic Bach, M.: Cluster Analysis of Internet Usage in European Countries, Annals of DAAAM for 2012 \& Proceedings of the 23rd International DAAAM Symposium, ISBN 978-3-901509-91-9, ISSN 2304-1382, pp 0525 - 0528, Editor B[ranko] Katalinic, Published by DAAAM International, Vienna, Austria, 2012.

[28] Sinkovics, N., Sinkovics, R. R., \& "Bryan" Jean, R. (2013). The internet as an alternative path to internationalization? International Marketing Review, 30(2), 130-155. doi:10.1108/02651331311314556

[29] Gabrielsson, M., \& Gabrielsson, P. (2011). Internet-based sales channel strategies of born global firms. International Business Review, 20(1), 88-99. doi:10.1016/j.ibusrev.2010.05.001

[30] Draskovic, N., Pavicic, J., Vignali, G. \& Baric, Z. (2006). Advertising in Croatia: Historical and Environmental Change Framework. International Journal of Management Cases, Vol. 8, No. 3, 2006, pp. 21-32, ISSN: 1741-6264

[31] Kupinic Guscic, D. (2005). Market of 426 million Euros. Economic Bulletin, No. 3399, May 2005, pp. 16-23, ISSN 2459-8968 Kupinic Guscic, D. (2005). Trziste tesko 426 milijuna eura. Privredni vjesnik, No. 3399, May 2005, pp. 16-23, ISSN 2459-8968

[32] Antolovic, K. (2017). Advertising in Croatia from its beginnings till today, Available from: http://www.medijskapismenost.hr/oglasavanje-hrvatskoj-svojih-pocetaka-do-danas/ Accessed: 2017-07-19 Antolovic, K. (2017). Oglašavanje u Hrvatskoj od svojih početaka do danas, Available from: http://www.medijskapismenost.hr/oglasavanje-hrvatskoj-svojih-pocetaka-do-danas/ Accessed: 2017-07-19

[33] Letang, V. \& Stillman, L. (2016). Global advertising forecast: Winter update. MAGNA, New York.

[34] Macan, K. (2011). 7 TOP agencies for digital advertising in Croatia, Available from: http://www.broj1.hr/2011/08/18/7-top-agencija-za-digitalno-ogla\%C5\%A1avanje-u-hrvatskoj Accessed: 2017-0719 Macan, K. (2011). 7 TOP agencija za digitalno oglašavanje u Hrvatskoj, Available from: http://www.broj1.hr/2011/08/18/7-top-agencija-za-digitalno-ogla\%C5\%A1avanje-u-hrvatskoj Accessed: 2017-0719

[35] Ipsos Connect (2014). Agency Census 2014, Available from: http://hura.hr/wp-content/uploads/2016/11/HURAagencijski-cenzus-2014-1.pdf Accessed: 2017-07-19 Ipsos Connect (2014). Agencijski census 2014, Available from: http://hura.hr/wp-content/uploads/2016/11/HURA-agencijski-cenzus-2014-1.pdf Accessed: 2017-07-19

[36] Dupanovic, E. (2015). Ilija Brajković: Most digital agencies are doing social network campaigns at unrealistically low prices. Media Marketing, Available from: http://www.media-marketing.com/intervju-dana/ilija-brajkovicvecina-digitalnih-agencija-rade-kampanje-na-drustvenim-mrezama-po-nerealno-niskim-cijenama/ Accessed: 2017 07-19, Dupanovic, E. (2015). Ilija Brajković: Većina digitalnih agencija rade kampanje na društvenim mrežama po nerealno niskim cijenama. Media Marketing, Available from: http://www.media-marketing.com/intervju-dana/ilijabrajkovic-vecina-digitalnih-agencija-rade-kampanje-na-drustvenim-mrezama-po-nerealno-niskim-cijenama/ Accessed: 2017-07-19

[37] Kranjec, R. (2015). Letter from Azerbaijan: Bruketa\&Žinić OM in "fiery" country of incredibly fast changes, Available from: http://www.media-marketing.com/kolumna/pismo-iz-azerbajdzana-bruketazinic-om-u-vatrenojzemlji-nevjerojatno-brzih-promjena/ Accessed: 2017-07-20, Kranjec, R. (2015). Pismo iz Azerbajdžana: Bruketa\&Žinić OM u "vatrenoj" zemlji nevjerojatno brzih promjena, Available from: http://www.mediamarketing.com/kolumna/pismo-iz-azerbajdzana-bruketazinic-om-u-vatrenoj-zemlji-nevjerojatno-brzih-promjena/ Accessed: 2017-07-20

[38] Bruketa\&Zinic OM (2017). Bruketa\&Žinić OM sold stakes in Baku, Belgrade and Brokuli\&Ž, Available from: http://bruketa-zinic.com/hr/2017/04/27/bruketazinic-om-prodali-udjele-u-bakuu-beogradu-i-brokuliz/ Accessed: 2017-07-20, Bruketa\&Zinic OM (2017). Bruketa\&Žinić OM prodali udjele u Bakuu, Beogradu i Brokuli\&Ž Available from: http://bruketa-zinic.com/hr/2017/04/27/bruketazinic-om-prodali-udjele-u-bakuu-beogradu-ibrokuliz/ Accessed: 2017-07-20 